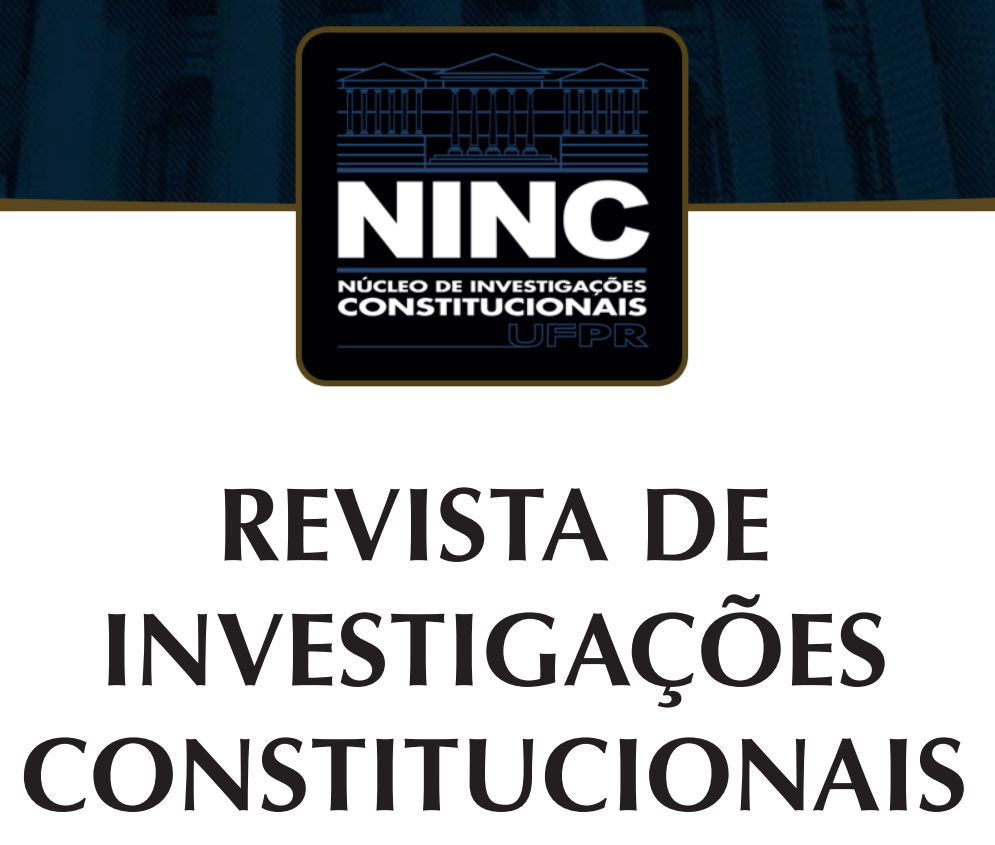

JOURNAL OF CONSTITUTIONAL RESEARCH

vol. 7 | n. 2 | maio/agosto 2020 | ISSN 2359-5639 | Periodicidade quadrimestral Curitiba | Núcleo de Investigações Constitucionais da UFPR | www.ninc.com.br 


\title{
Amendments of Russian constitution concerning international law and the BRICS
}

\section{Emendas à Constituição Russa relativas ao Direito Internacional e aos BRICS}

\author{
MICHEL VERLAINE ${ }^{l, *}$ \\ 'Institute of Child Nutrition Business School (Paris, France) \\ michel.verlaine@icn-artem.com \\ https://orcid.org/0000-0001-6269-5336 \\ ANNA SHASHKOVA $11, * *$ \\ " Moscow State Institute of International Relations (Moscow, Russia) \\ a.shashkova@inno.mgimo.ru \\ https://orcid.org/0000-0003-3825-8341

\section{EKATERINA KUDRYASHOVA ${ }^{\text {III, *** }}$} \\ III Institute of Legislation and Comparative Law (Moscow, Russia) \\ ev_kudryashova@inbox.ru \\ https://orcid.org/0000-0002-7029-5794 \\ Recebido/Received: 30.04 .2020 / April $30^{\text {th }}, 2020$ \\ Aprovado/Approved: $17.10 .2020 /$ October $17^{\text {th }}, 2020$
}

\section{Abstract}

The paper presents the current constitutional reform in Russia focusing on the constitutional amendment concerning the international case law. The amended article 79 of the Constitution of Russian Federation restricts the international case law applicability in Russia. There

\section{Resumo}

O artigo apresenta a atual reforma constitucional na Rússia com foco na emenda que diz respeito à jurisprudência internacional. $O$ emendado artigo 79 restringe a aplicabilidade das resoluções de instituições internacionais para a Rússia. Está de acordo com a abordagem positivista do

\footnotetext{
Como citar esse artigo/How to cite this article: VERLAINE, Michel; SHASHKOVA, Anna; KUDRYASHOVA, Ekaterina. The prospective amendments of Russian constitution concerning international law and the BRICs. Revista de Investigações Constitucionais, Curitiba, vol. 7, n. 2, p. 337-353, maio/ago. 2020. DOI: 10.5380/rinc.v7i2.73355.

* PhD in Economics and Management, Institute of Child Nutrition Business School - ICN Business School (Paris, France). E-mail: michel.verlaine@icn-artem.com.

** Doctor of Science (Politics), Candidate of Science (Law), Professor of Constitutional Law Chair, Moscow State Institute of International Relations (Moscow, Russia). E-mail: a.shashkova@inno.mgimo.ru.

*** Doctor of Science (Law), Head researcher of the Institute of legislation and comparative law under the Government of Russian Federation (Moscow, Russia). Attorney at law. E-mail: ev_kudryashova@inbox.ru.
} 
was no polemic around the draft of the constitutional amendment and this restriction was accepted by experts, politicians and public without any discussion. To certain extent this unanimous acceptance could be explained by general positivistic trend in Russia. The amendment is in line with the positivistic approach to the international law formed in Russia recently. The strategic documents on the cooperation within BRICS are scrutinized showing that the positivistic approach is in line with the strategies of Russia announced previously. Based on the general scientific methods and on the method of academic foresight the authors made the following conclusions. The constitutional reform regarding international law does not affect the BRICS documents directly and it does not go against the principles of BRICS cooperation announced by Russia. However, there are certain indirect implications. It is clear that the reform deepens divergences between the BRICS countries. The differences in the approaches to the human rights, certain ideological differences will become more acute within BRICS and there is a space for political use of these differences.

Keywords: BRICS; constitutional reform in Russia; Russian constitution; political pragmatism; sources of international law. direito internacional formada recentemente na Rússia. Os documentos estratégicos sobre a cooperação no BRICS são examinados mostrando que a abordagem positivista está em linha com as estratégias da Rússia anunciadas anteriormente. Com base nos métodos científicos gerais e no método de previsão acadêmica, os autores chegaram às seguintes conclusões. A reforma constitucional em matéria de direito internacional não afeta diretamente os documentos do BRICS e não vai contra os princípios de cooperação do BRICS anunciados pela Rússia. No entanto, existem certas implicações indiretas. É claro que a reforma aprofunda divergências entre os países do BRICS. As diferenças nas abordagens dos direitos humanos e certas diferenças ideológicas se tornarão mais agudas dentro dos BRICS, de modo que há um espaço para o uso político dessas diferenças.

Palavras-chave: BRICS; reforma constitucional na Rússia; Constituição russa; pragmatismo político; fontes do direito internacional.

\section{CONTENTS}

1. Introduction; 2. General considerations on the constitutional reform 2020 in Russia; 3. The essence of the constitutional amendments 2020 concerning the international law; 4 . The future of the BRICS grouping and the BRICS law; 5 . Discussion and conclusions; 6 . References.

\section{INTRODUCTION}

In January of 2020 the President of Russian Federation addressed to the nation and announced the modification of the Russian Constitution. The first draft of the amendments was submitted to the Federal Assembly (parliament) and the nation-wide discussion was initiated. The national voting on the novelties was announced to be the prerequisite of the constitutional changes.

The text of constitutional amendments contains changes related to the Russian approach to the international law. The article 15 (4) of the Russian Constitution giving the priority to the international treaties in the Russian legal order stay intact. However, the international case law application is restricted. In brief, the constitutional amendment 2020 restricts the binding force of the interstate body resolutions. Further in this article we shall give the precise wording of the amendment. 
The amendment concerning the international case law application was presented in the initial draft of the constitutional modifications and the whole process of the constitutional reform showed that this part of the initial draft was not criticized or even commented. The list of the initial amendments was amplified rather than rejected or restricted. Within the course of the nation-wide discussion a few additional social and political amendments were submitted to the Federal Assembly leaving the initial text of the amendments untouched.

The Russian constitutional reform coupled with Russia's chairing of BRICS (Brazil, Russia, India, China and Sauth Africa). The January of 2020 was the first month than Russia started to be the chairman of BRICs. Russia took over the chair position in BRICS with the motto "BRICS Strategic Partnership for Global Stability, Shared Security and Innovative Growth". Russia took the presidency declaring the special focus on enhancing cooperation primarily within the United Nations.

It is timely to start the academic discourse as the Russian constitutional reform turns to be very important in the multipolar international cooperation. It is relevant to express the view and make some educated guess on the implications which could be expected.

It is acknowledged in the academic literature that the Russian constitutional practice in respect of international law was drastically understudied before 2014'. The situation has been improving somewhat since 2014. However, still not many publications appear on the international academic environment with analysis of Russian concepts and approaches. The sanctions and general context predefined that only discrete aspects were attractive for international academics.

The methods of the article include the historical method because it will help to enlighten the background for many constitutional changes. The evaluating legal processes methods and the interpretational analysis shall be used in this research as the BRICS is rather a cooperation in dynamic rather than static institutionalized organization. The complicated nature of the most of the processes within the BRICS renders its effective research multidisciplinary and multifaced involving the politics, law and other social sciences.

The methods of analysis and synthesis are matching this research most of all. The general background of constitutional reform in Russia and the relevant constitutional changes in Russia shall be commented firstly. Than the genesis and the future of the BRICS cooperation will be studied. After the separate overview the future implications of the constitutional changes in Russia for the BRICS relations shall be under academic scrutiny.

MALKSOO, Lauri. Russian Approaches to International law. Oxford: Oxford University Press, 2015. 
The hallmark of this paper is the endeavor to have a look into the future. Inevitably, the academic foresight method will help us to fulfill our tasks. Academic foresight makes this research distinct from other law studies which are usually carried out only post-factum with reference to the documents already in force and finalized cases.

The basic question to be posed at this stage of constitutional reform in Russia is about the meaning of the constitutional amendments concerning international law for the international cooperation within the BRICS. The problem of future interaction of domestic and international law including the emerging notion of BRICS law shall be explored. Our hypothesis is that the constitutional amendments affect mostly the role of international case law produced by the institutional interstate bodies. Therefore, the cooperation within BRICS is not affected straightforward. However, certain reservations should be made. The constitutional changes restricting the case law application in Russia amount to a divergence in the views on the international law among the BRICS member-states, especially taking into account the more and more apparent trend "west against the rest". This shall be a politically sensitive issue potentially casting its reflection on the future cooperation within the BRICS.

\section{GENERAL CONSIDERATIONS ON THE CONSTITUTIONAL RE- FORM 2020 IN RUSSIA}

The current Constitution of Russia was adopted in 1993 on the nation-wide referendum after the collapse of the USSR. Just like the most of the liberal constitutions in the world the Russian Constitution of 1993 was drafted in the situation of social cataclysm with clashes of ideologies when the passions run high and disagreements become irreconcilable ${ }^{2}$. Russian constitution shares the features of the post-socialist constitutions which were supposed to meet the demands of their time rather than articulate the final resolution of social disagreements.

Given all these contextual matters the social consensus was hardly achieved and immature for a while and the stability was an absolute value. Therefore, the ideas of constitutional reform were rejected for a long time. Since 2001 the President of Russia in his various official speeches denied even the possibility of constitutional redesign. The scenario of constitutional modernization stated to be mentioned only since 2007 and since than raised mounting to the desired natural step on the way of Russian constitutionalism.

The academic society was not unanimous in the assessment of the constitutional reform. In the early 2000-s many prominent academics already supported the

2 ELSTER, Jon. Constitution-making and violence. Journal of Legal Analysis, Oxford, v. 4, n. 1, p. 7-39, mar./ may. 2012. 
stability of constitution and it was a little awkward to reconsider their stance and reopen the discourse. However, by the 2019 both Russian academics reconciled with the public opinion and official position that the constitutional reform is desirable

In fact, the Constitution of the Russian Federation was changed many times. The detailed and impartial analysis of the amendments draft 2020 which was initially submitted to the Federal Assembly demonstrates that it does not make difference to many others constitutional modifications previously adopted without any political fuss around them. If the constitutional reform shall stick to the initial presidential draft than no special complicated procedure is needed for their coming into force ${ }^{3}$. In the course of the nationwide discussion there were some other amendments introduced and they are affecting the so-called eternity clauses of the Russian Constitution 1993. In this case the cumbersome and long procedures shall need to be arranged.

Constitutions get matured through application by all the actors including the judicial and executive powers ${ }^{4}$. During the last twenty years of constant reforms, eventful political life and ever changing international context the constitutionalism in Russia passed a way of establishment. The constitutional reform of 2020 in some matters reveals the already established concepts. This is the case of the constitutional amendment concerning international case law.

In terms of the international law Russian Constitution of 1993 was known to be the most friendly comparing to the constitutions of the post-Soviet area as Russia has the only Constitution with "integration clause"5. After a while it became a challenge to preserve the sovereign views and keep pace to the changes of the external context. During the recent years certain approaches to the international law grew to mature inside Russian political and judicial practice. The amendment to the Constitution 2020 is reaffirming the supremacy of the Constitution over any decisions of international bodies. The reputation of most-friendly constitution is gradually foregone in 2017-2020 for the international case law aspects. Although for the treaties and agreements the integration clause is still in place in the Russian Constitution.

\footnotetext{
3 SHASHKOVA, Anna; VERLAINE, Michel; KUDRYASHOVA, Ekaterina, On modifications to the Constitution of the Russian Federation in 2020. Russian Law Journal, Moscow, v. 8, n. 1, p. 60-83, 2020.

4 BUTLER, William. Five Generations of Russian Constitutions: Russia as part of the Western Legal Heritage, BRICS Law Journal, Tiumen, v. 6, n. 3, 2019, p. 13-21.

5 KALINICHENKO, Paul. The constitutional order of the Russian Federation and its adaptability to European and Eurasian integration Project. In: PETROV, Roman; ELSUWEGE, Peter (Eds.). Post-Soviet Constitutions and Challenges of Regional Integration. Adapting to European and Eurasian Integration Projects. Abingdon: Routledge, 2018, p.168-177.
} 


\section{THE ESSENCE OF THE CONSTITUTIONAL AMENDMENTS 2020 CONCERNING THE INTERNATIONAL LAW}

Describing the current constitutional reform concerning international law we shall start with the provision which is left unchanged. The part 4 article 15 of the Constitution of Russian Federation preserved the same wording. It is still ensuring the recognition of the international law norms as well as the international treaties and agreements of the Russian Federation. The international law according to this provision is still a part of the Russian legal system. If an international treaty or agreement of the Russian Federation provides the rules other than those in the domestic law, the rules of the international agreement shall be applicable. The part 4 article 15 can be found in the chapter 1 "The Fundamentals of the Constitutional System" which is secure from constant changes by the cumbersome procedures.

The article 17 of the Constitution will not undergo any changes in the nearest future. It states that in the Russian Federation recognizes and guarantees the rights and freedoms of man and citizen according to the universally acknowledged principles and norms of international law and according to the Constitution.

The issues of international law applicability in Russia were officially clarified for the Russian judicial practice just a few years after the Constitution 1993 came to force. The Supreme Court of the Russian Federation explained in its official document dated $1995^{6}$ that only the officially published international treaties which do not require any domestic acts should have direct application in the court hearings. The immediate effect of the officially promulgated international treaties rules was confirmed by the Supreme Court in $2003^{7}$.

Thus, we can mark a positivistic trend in the approach to the international law in Russia leading to the narrowing the range of its sources. Not all the treaties have immediate effect, but only those which do not require the further acts for their implementation.

The President Putin in his addressing to the Federal Assembly in January 2020 expressed the general willingness to guarantee the priority of Constitution. Literally it means according to the addressing that only if the international legislation and treaties requirements, as well as the decisions of international bodies do not imply contradiction to the Russian Constitution - they can be in effect in Russia. ${ }^{8}$

\footnotetext{
6 RUSSIAN FEDERATION. The Resolution the Supreme Court of the Russian Federation (Plenum) of 31 October 1995 n. 8 "About some questions of applying the Constitution of Russia by the courts in the course of justice".

7 RUSSIAN FEDERATION. The Resolution of the Supreme Court of Russian Federation (Plenum) of 10 October 2003 n. 5 «About the applying by courts the generally recognized principles and norms of international law and international treaties of the Russian Federation".

8 ПРЕЗИДЕНТ РОССИИ. Послание Президента Федеральному Собранию. Moscow. Available at: <http:// www.kremlin.ru/events/president/news/62582>. Last accessed: 20 feb. 2020.
} 
This message has evolved in a new wording of the article 79 of the Constitution presented in the draft of Federal constitutional law "On the amendment of the Constitution" introduced to the Federal Assembly shortly after the addressing to the nation. We already referred to this draft as the initial presidential draft of the amendments.

Before the proposed revisiting the provision of article 79 stated: "The Russian Federation may participate in interstate associations and transfer to them part of its powers according to international treaties and agreements, if this does not involve the limitation of the rights and freedoms of man and citizen and does not contradict the principles of the constitutional system of the Russian Federation".

The revised article 79 has a broader wording. According to the amended version the decisions of interstate bodies adopted based on the provisions of international treaties concluded by the Russian Federation and interpreted in a way contradicting the Constitution shall not be enforced in Russia.

The chapter 3 "Federal structure" of Russian Constitution where we find the article 79 is not subject to the special procedures in order to change it. The Chapters 3-8 can undergo changes according to the rules specified for federal constitutional laws. Namely, the amendments to chapters 3-8 come into force after the approval by the legislative assemblies of not less than two thirds of the subjects of federation.

No special procedures with a special constituent congress or nation- wide voting are necessary for changing article 79 of Russian Constitution. Thus, the article 79 shall be amended anyway even if the nation-wide voting shall not take place for any reasons. The initial draft of the amendments to the Russian constitution are outside the scope of the eternity clauses entailing the complicated, long and cumbersome procedure to be changed. That is the formal reason why we are quite sure that our discourse on the amended article 79 of Russian Constitution is relevant right now.

The revisited article 79 is reaffirming the positivistic restrictive approach already well-established in Russian legal order and practice. It could be considered that the amendment of article 79 of the Constitution is just aimed to reinforce Russia's position with regard the recent decisions of the European Court of Human Rights. However, it is true only partially. This is not the ongoing situation and tackling problems sporadically arising in international relations. The amended article 79 reflects the positivistic traditions in Russia and affirms already existent trend to positivism in law.

Positivist tenets require the interpretative process to be guided not by abstract political morality with unclear origins, but by general interpretation rules including the interpretation in good faith revealing the common intention of the parties ${ }^{9}$. Recently,

9 ZAKHAROVA, Larissa. The interpretive approach to international law: a positivist view. Kutafin University Law Review, Moscow, v. 2, n.1, p. 136-155, may. 2015. 
the judicial practice in Russia even considered to be defensive and isolationistic though it is just within the positivistic trend.

The detailed track of the cases where the positivistic tenets were revealed shall lead aside from our research question therefore we shall make only a short remark.

The difference in the approaches of the European Court of Human Rights and the Constitutional Court of Russia was the main line in the Russian judicial practice leading to the restrictions of the international case law application in Russia. The Constitutional Court of Russia took the view that it is not possible to enforce the decision of the interstate body once it is based on the conflicting with the Russian Constitution interpretation of the international treaty, no matter that Russia was a party to that treaty. This gap in the views on the interpretation of international law turned up before 2007 and than the cases with controversial interpretation piled up. Recently the most tensy case of Yukos in the European Court of Human Rights was finalized to the detriment of the Russian Federation.

The right of the Constitutional Court to reject the interpretative views of international bodies was legalized by the changes to the Federal Law on the Constitutional Court of the Russian Federation. It seemed to be not enough in the growing pressure on Russia and now the positivistic trend shall have its place in the Constitution of Russia.

\section{THE FUTURE OF THE BRICS GROUPING AND THE BRICS LAW}

Since 2001 when the notion BRICS appeared in the international routine lexicon this notion existed without a real basis for any political or other identification. It was until 2009 when the leaders of the BRICs met as a group. Over the decade since 2009 the BRICS developed from the club with specific interests to an effective mechanism of strategic partnership in various fields. The scope of BRICS does not amount to entire political, economic and cultural cooperation and it is rather a kaleidoscope of common interests and mutual benefits. The lack of rigid institutionalization, charters, headquarters and staff was presented as the advantage and strong side of BRICS on the web site of Russia's presidency in 2020. The culture of cooperation and "BRICS spirit" is an important achievement of the first decade of BRICS. ${ }^{10}$

Five major economies are brought together in the BRICS. In 2016 these countries were already representing the population of around 43 percent of the world population, 17 percent share of the trade and 30 percent of the worlds GDP ${ }^{11}$ In 2016 the

\footnotetext{
10 RUSSIAN FEDERATION. Website of Russia's Presidency in the BRICS 2020. Available at: <https://eng.bricsrussia2020.ru>. Last accessed: 10 apr. 2020.

11 INDIA. Website of India's 2016 BRICS, 'About BRICS'. Available at: <http://brics2016.gov.in/content/ innerpage/about-usphp.php>. Last accessed: 10 apr. 2020.
} 
BRICS was described as a phenomenon of international politics, contesting the international order on the basis of their economic and political development.

BRICS was characterized as a state-centric association where no leader prevails over others. Though in certain researchers sometime call BRICS "China-led" association vesting the leading role into China, because China gains less than other countries out of this political alliance but has more leverage than other participants ${ }^{12}$. Russia is alleged to fit in BRICS only as a country with certain valuable geo-political attributes and not as a fast-growing country and invited to BRICS ${ }^{13}$.

It is quite obvious that BRICS does not amount to the international organization. The academic studies demonstrate that BRICS does not amount even to an international regime because in this case it should have produced converging principles, norms or decision-making process. The "grouping" is widely used for BRICS definition entailing the independent decision-making, subsequent action taking and compartmentalizing the activity. BRICS relies more on expectations rather on obligations ${ }^{14}$. The BRICS is also referred as "dialogue and cooperation" platform".

Recently BRICS announced a BRICS Plus strategy which seeks to promote new platform for regional and bilateral alliances across the continents. The BRICS Plus aims to bring together the regional blocks like Mercosur, South African Customs Union (SACU), Eurasian economic union, ACEAN FTA, European Union etcetera. It is very important that the new BRICS Plus strategy focuses on collaboration and not competition with major international organizations. ${ }^{16}$ The uninstitutionalized grouping without formal treaties allow to fulfill this strategy. Otherwise there would be inevitable competition of documents like this is the case for the Eurasian economic union legal system and, for example, the World Trade Organization documents.

BRICS does not rely on permanent institutions and no single authoritative source of BRICS documents is available. The BRICS Informational Portal was started, but it is far from being considered official texts ${ }^{17}$. The official portal is the BRICS presidency official site. ${ }^{18}$

12 GARCÍA, Arturo Oropeza. The role of China and the BRICS project. Mexican Law Review, México, v. 7, n. 1, p. 109-136, jul./dec. 2014.

13 COOPER, Andrew F. The BRICS: A Very Short Introduction. Oxford: Oxford University Press, 2016.

14 BROSIG, Malte. The Role of BRICS in Large-Scale Armed Conflict. New security challenges. London: Palgrave Macmillan, 2019, p. 1-41.

15 NEUWIRTH, Rostam J.; SVETLICINII, Alexandr. The BRICS-Lawyers' Guide to BRICS Texts and Materials. Macau: BRICS-Lawyers, 2019.

16 WORLD ECONOMIC FORUM. BRICS-plus: Alternative globalization in the making? Available at: <https://www.weforum.org/agenda/2018/01/brics-plus-an-alternative-to-globalization-in-the-making/>. Last accessed: 10 apr. 2020.

17 BRICS INFORMATION PORTAL. Available at: <http://infobrics.org>. Last accessed: 10 apr. 2020.

18 RUSSIAN FEDERATION. Website of Russia's Presidency in the BRICS 2020. Available at: <https://eng.brics-russia2020.ru>. Last accessed: 10 apr. 2020. 
BRICS has only two BRICS financial institutions: the New Development Bank (NDB) and the Contingent Reserves Arrangement (CRA). They cover only a very narrow fields of cooperation and until now do not issue any resolutions. It is questionable if BRICs at all will develop any consistent position in international economic law. ${ }^{19}$

Given all those considerations about the controversial nature of the BRICS as a grouping of countries there are already academic publications about the emerging BRICS law, because there is still no unanimous agreement on the scope of the notion "source of law" for BRICS. The discussion goes around potentially modern sources of law appearing within BRICS. Good attempts is already made to elaborate compendium of principle texts shaping the cooperation within the BRICS which should be mentioned here. In the introductory analytical part preceding the compellation the BRICS law is presented as an appearing legal order ${ }^{20}$.

We would agree only with careful appraisal of the BRICS sources as an emerging system of international law sources. It could be admitted that there is a good potential for development of the documents which may become valid sources of international law. Especially, once we look into the future of the international relations.

The energy sector should be mentioned as the field where certain regulative activity shall arise. The Delhi Declaration of 2012 launched the cooperation and general development of relations in the energy field. BRICS Summit in Ufa on July 9, 2015 pushed the economic cooperation in all spheres by means of the BRICS Economic Partnership Strategy where the importance of promoting energy cooperation with sharing experiences in the areas related to energy production and consumption, energy planning was emphasized ${ }^{21}$. The further cooperation in energy sectors supposes the formation of a single legal space. The experts insist on the need for the unification of the national legislation relevant for the energy sector. The single legal space is supposed to advance the integration process and support the international legal status of BRICS. ${ }^{22}$ The macroeconomic strategic coordination without dominance of any actor becoming popular basis for alliances and associations. ${ }^{23}$ Within the unification process some forms

\footnotetext{
19 ROLLAND, Sonia E. The BRICS' Contributions to the Architecture and Norms of International Economic Law Proceedings of the Annual Meeting. American Society of International Law, Massachusetts, v. 107, 2013, p. 164-170.

20 NEUWIRTH, Rostam J.; SVETLICINII, Alexandr. The BRICS-Lawyers' Guide to BRICS Texts and Materials. Macau: BRICS-Lawyers, 2019.

21 RYAZANOVA, M. O. Energy cooperation within the BRICS: Significance of the issue. Bulletin of MGIMO, Moscow, v. 39, n. 6, p. 7-11, 2015.

22 INSHAKOVA, Agnessa O.; MARCHUKOV, Igor P. General Energy Policy and Ways of Development of Legal Regulation of Foreign Trade Turnover of Energy Resources of the BRICS Countries. In: INSHAKOV, Oleg V.; INSHAKOVA, Agnessa O.; POPKOVA, Elena G. (Eds.). Energy Sector: A Systematic Analysis of Economy, Foreign Trade and Legal Regulations Lecture Notes in Networks and Systems. Switzerland: Springer, 2019, p. 227-245.

23 SHOKHIN, Sergey; KUDRYASHOVA, Ekaterina. Macroeconomic Coordination in the Eurasian Economic Union: Strategic Aspects. Russian Law Journal. Moscow, v. 7, n. 3, 2019, p. 38-52.
} 
of law sources could be expected. Especially as the energy and energy security are the most important cooperation points.

There is a visible intention the further cooperation in the competition law. On 19 May 2016 in St. Peterburg a memorandum of understanding in the field of competition policy to strengthen the cooperation and coordination between the BRICS Competition Authorities was signed. The formal ground for the inter-institutional cooperation was created and some kind of interinstitutional agreement could be expected in the nearest future.

Another field with good prospects for further development of formal sources within the BRICS is the international investment law and in particular the protection of investment and dispute resolution. The suggestions to impose expressed and clear obligations on the host states for the foreign investments appeared in the agenda of BRICS in 2015. It was based on the intention to interact closer stimulating the mutual investments streams. New forms of cooperation in addition to those already set in bilateral investment treaties were proposed including joint committees, special ombudsmans as well as monitoring of the investment agreement implementation. The investor-state dispute resolution was a special concern of the experts searching for the ways to assist to the investment flow increase. ${ }^{24}$ The attempts to impose any kind of additional obligations on the host states imply a formal documents sooner or later.

Finally, it should be mentioned that shortly after the BRICS became a platform for dialogue between the countries an academic study on possible Free Trade Agreement was published. The Free Trade Agreement with different hypothetical scenarios was found to be beneficial for all the member-counties nearly in any scenario of cooperation $^{25}$ This finding suggests that sooner or later certain form of integration beneficial for all the parties can be expected and it is likely to be build.

\section{DISCUSSION AND CONCLUSIONS}

Nowadays BRICS is defined as a grouping of states with shared interests in the international politics. The new modern way of cooperation and its special spirit were shaped within BRICS in the recent decades. The lack of formalism allows further cooperation with the regional blocks and associations relying mostly on the political cooperation on a narrow issue and avoiding the conflict of documents.

Still by now there is a whole bulk of declarations and other documents of a specific nature elaborated within the BRICS platform. BRICS law as an emerging

24 SIMÕES, Fernando Dias. A Dispute Resolution Center for the BRICS? In: NEUWIRTH, Rostam J.; SVETLICINII, Alexandr; HALIS, Denis de Castro (Eds.). The BRICS-Lawyers' Guide to Global Cooperation.Campridge: Cambridge University Press, 2017, p. 270-286.

25 SANDREY, Ron; JANSEN, Hans Grinsted. A fresh look at a Preferential Trade Agreement among the BRICS. Stellenbosch: Tralac, 2013. 
phenomenon can be admitted giving overtures to the further development. We mentioned the main directions of BRICS cooperation development where potentially may appear the modern or traditional sources of international law. Anyway the BRICS sources are part of the contemporary international reality and they cannot be just discarded and ignored by the international legal practice. Taking this into consideration we still find it appropriate to pose the problem of interaction of domestic legal orders and the BRICS bulk of law sources.

The BRICS emerging modern sources of law are not formal enough to meet the requirements of the positivistic approach promoted in Russia by now. The BRICS documents are by no means can be immediately and directly applicable in Russia. The influence of the BRICS documents in the Russian domestic legal order are not secured by the part 4 of article 15 of the Constitution of Russia.

There are no interstate institutions in the BRICS framework which resolutions could fall within the scope of the revised article 79 of Russian Constitution and which could soon become inapplicable in Russia. It can be the case only if the BRICS drifts towards the regional economic integration with its institutions or towards international organization Russian positivistic approach. This seems to fall outside the BRICS spirit and culture of cooperation especially taking into account the BRICS Plus agenda.

At the same time there are a few understreams and indirect implications for the future cooperation within BRICS arising from the constitutional reform in Russia. This implication deserves an overview and discussion here.

The controversial findings on the drastic differences between the BRICS countries are becoming popular in academic circles. The differences include the political issues and ideologies, incompatibilities of the democratic multi-party regimes of Brazil, India and South Africa and non-democratic regime of Russia and China. Organizational, political and strategic culture differences are emphasized especially with regard to the investment and doing business aspects. Another concern is that the risk rating for all five countries increased including the violence, government interference and sovereign non-payment risk $^{26}$. Besides just acknowledging of the differences between the BRICS members it is implicitly pointed out that the risk ratings of all the BRICS countries are possibly affected by their grouping and not in a positive way.

Far more explicit allusions to a "bad company" in BRICS can be found in respect of the international law issues. For example, it is suggested to the South Africa to weight its commitment to the liberal values and understanding of human rights that underlie the contemporary legal order while associating with the emerging powers within the BRICS. The question is posed if it is strategically right to cooperate within BRICS with

26 ASUELIME, Lucky E. The cons of South Africa's membership in a China-led BRICS: an appraisal. Journal of African Union Studies, Johannesburg, v. 7, n. 1, p. 115-128, apr. 2018. 
the countries with their own views on certain issues of human rights. ${ }^{27}$ In respect of human rights it is emphasized in academic writing that Brazil like other BRICS-members accepts the priority of sovereignty, highly appreciates the international cooperation within BRICS. Though Brazil plays with "western rules" and does not try to change the system, only intending to reach higher position in the hierarchy of international powers. ${ }^{28}$

It is widely encouraged and accepted that the divergences in the political systems and approaches to the international law eligible for the pragmatic political approach to cooperation. The political problems usually supported by economic measures. For instance, the flows of international investments are usually very sensitive to the political environment and the foreign investments stimulation is in the most promising fields of the BRICS cooperation.

The constitutional reform in Russia, shaping its positivistic approach to the interpretative aspects of international law is likely to fall within the category of imbalances between the BRICS members.

The Russian restrictive approach to the international case law especially the discrepancy in the interpretation of the human rights treaties can provoke political uses and misuses but only without any sound basis. The conformity of Russian constitutional amendments with the BRICS cooperation culture follows from the BRICS declarations precluding the political connotation or double standards interpreting the international law.

In the declarations promulgated in the BRICS the general concern about the international law and its development in the world is expressed. In the Ufa Declaration (Ufa, the Russian Federation, 9 July 2015) ${ }^{29}$ the international law was especially noted emphasizing that the BRICS countries rely on the international law as a tool of international justice consistent with good faith and sovereign equality. It was highlighted that principles and rules of international law should be adhered in their integrity and interrelation. The double standards and restrictions of certain countries interests according to the Ufa Declaration should be discarded.

The BRICS cooperation refers to the integrity of the international law, but it envisages the pluralism of the views in the approaches of each end every member-state.

Although the international law should not be fragmentated according to the views of different countries, still the divergences in the interpretation of it are allowed and even welcomed by international law doctrine. The interrelations of international

27 SMITH, K. South Africa, the BRICS and human rights: In bad company? In: KHADIAGALA, Gilbert M.; PILLAY, Devan; SOUTHALL, Roger (Eds.). New South African Review 5: Beyond Marikana. Johannesburg: University of Witwatersrand Press, 2015.

28 DEHSHIRI, Mohammad Reza; NESHASTESAZAN, Mohammad Hossein. Human Rights Diplomacy: Case Study of Brazil. Journal of World Sociopolitical Studies, Tehran, v. 2, n. 1, 2018.

29 RUSSIAN FEDERATION. Website of Russia's Presidency in the BRICS 2020. Available at: <https://eng.brics-russia2020.ru>. Last accessed: 10 apr. 2020. 
and domestic legal orders give space for development in and the rules of international law are accepted and allowed into domestic order by the countries rather than imposed to the sovereigns. Becoming a part of the domestic legal order the international law is inevitably interpreted by means of specific social, political and cultural environment $^{30}$. The internal legal order passes through the filter of the domestic legal system. ${ }^{31}$

It should be admitted that the revision of the article 79 of the Russian Constitution does not add much to the already mature approach of Russia to the international law which is in line with the long traditions. Restricting the application of the international case law Russia reaffirms its positivistic approach to the international law and in particular to the interpretation of international case law. The international law and treaties requirements, as well as the decisions of international bodies in conflict with the Russian Constitution are not valid in Russia and not applicable in the political and judicial practice.

Basically, similar declarations to the sense of supremacy of Russian Constitution can be found in many documents in Russia long before the constitutional reform. In the early stage of BRICS grouping Russia issued a special policy statement - Concept of participation of the Russian Federation in BRICS (the Presidential decree of 15 April 2013). ${ }^{32}$ The Concept states in the first lines that it is based on its Constitution, federal legislation, generally accepted principles and norms of international law, international treaties to which the Russian Federation is a party, policy documents adopted at BRICS summits, statutory instruments regulating activities of the federal authorities in the area of foreign policy, as well as a few strategic domestic documents of Russia in the foreign policy field which are becoming in reality far more influential sources than just political declarations. ${ }^{33}$ In fact Russia pursued the concept relentlessly.

The Concept clearly outlines that the relations between Russia and other BRICS members are based on the UN Charter and generally accepted principles and norms of international law, as well as principles agreed upon within the BRICS including openness, pragmatism, solidarity, non-bloc character and nonaggressive nature with regard to third parties.

Russia stick to the line of its foreign policy and in 2018 confirmed its commitment not to allow the unilateral interventions and double standards of judgement,

\footnotetext{
30 HANQUIN, Xue. Chinese Contemporary Perspective on International Law: History, Culture and International Law. The Hague Academy of international law Collected Courses. Vol. 355. Leiden: Martinus Nijhoff Publishers, 2011, p. 41-234.

31 CRAWFORD, James. Chance, Order, Change: the course of international law. General Course on Public International Law. Leiden: Martinus Nijhoff Publishers, 2014, p. 174.

32 [s.a.]. Concept of participation of the Russian Federation in BRICS. Available at: <http://static.kremlin. ru/media/events/eng/files/41d452b13d9c2624d228.pdf>. Last accessed: 15 oct. 2020.

33 KUDRYASHOVA, Ekaterina. Pravovoe regulirovanie strategicheskogo planirovaniia v sfere gosudarstvennykh finansov. Moscow: Institute zakonodatelstva i sravnitelnogo pravovedeniia, 2019.
} 
to disapprove the use of restrictive economic and military measures in international relations. $^{34}$

In the Concept of the Russian Federation participation in BRICS (p.14 e) Russia intended to enhance cooperation in the protection of human rights and fundamental freedoms in the world, to step up coordinated actions within the leading international organisations, especially the UN, as well as to fight jointly against attempts to politicize human rights issues and activities of specialized multilateral institutions.

The Russian formal Constitution and its application ceases to be unconditionally open for all and every resolved cases within the international law. The positivistic approach taken in the amendment 2020 to the Russian Constitution is within the framework of the intended way of cooperation within BRICS.

Although BRICS is only a grouping of the countries on the particular interests and many issues are falling outside its scope there are still discussions on the imbalances and divergences between the BRICS members which may be intolerable or used for political purposes.

The Russian constitutional reform regarding international law does not go against the principles of BRICS cooperation. However, in the ongoing international context it may be used in a very pragmatic political way by Russia's partners in the international cooperation and therefore affect the cooperation in the BRICS framework indirectly.

\section{REFERENCES}

ASUELIME, Lucky E. The cons of South Africa's membership in a China-led BRICS: an appraisal. Journal of African Union Studies, Johannesburg, v. 7, n. 1, p. 115-128, apr. 2018.

BRICS INFORMATION PORTAL. Available at: <http://infobrics.org>. Last accessed: 10 apr. 2020.

BROSIG, Malte. The Role of BRICS in Large-Scale Armed Conflict. New security challenges. London: Palgrave Macmillan, 2019, p. 1-41.

BUTLER, William. Five Generations of Russian Constitutions: Russia as part of the Western Legal Heritage. BRICS Law Journal, Tiumen, v. 6, n. 3, 2019, p. 13-21.

COOPER, Andrew F. The BRICS: A Very Short Introduction. Oxford: Oxford University Press, 2016.

CRAWFORD, James. Chance, Order, Change: the course of international law. General Course on Public International Law. Leiden: Martinus Nijhoff Publishers, 2014, p. 174.

DEHSHIRI, Mohammad Reza; NESHASTESAZAN, Mohammad Hossein. Human Rights Diplomacy: Case Study of Brazil. Journal of World Sociopolitical Studies, Tehran, v. 2, n. 1, 2018.

34 RICCERI, Marco. A report on the ambassador's conference in Rome following the 10th BRICS summit conference. Kutafin University Law Review. Moscow, vol. 6, n. 1, p. 225-234, apr. 2019. 
ELSTER, Jon. Constitution-making and violence. Journal of Legal Analysis, Oxford, v. 4, n. 1, p. 7-39, mar./may. 2012.

GARCÍA, Arturo Oropeza. The role of China and the BRICS project. Mexican Law Review, México, v. 7, n. 1, p. 109-136, jul./dec. 2014.

HANQUIN, Xue. Chinese Contemporary Perspective on International Law: History, Culture and International Law. The Hague Academy of international law Collected Courses. Vol. 355. Leiden: Martinus Nijhoff Publishers, 2011, p. 41-234.

INDIA. Website of India's 2016 BRICS, 'About BRICS.' Available at: <http://brics2016.gov.in/content/ innerpage/about-usphp.php>. Last accessed: 10 apr. 2020.

INSHAKOVA, Agnessa O.; MARCHUKOV, Igor P. General Energy Policy and Ways of Development of Legal Regulation of Foreign Trade Turnover of Energy Resources of the BRICS Countries. In: INSHAKOV, Oleg V.; INSHAKOVA, Agnessa O.; POPKOVA, Elena G. (Eds.). Energy Sector: A Systematic Analysis of Economy, Foreign Trade and Legal Regulations Lecture Notes in Networks and Systems. Switzerland: Springer, 2019, p. 227-245.

KALINICHENKO, Paul. The constitutional order of the Russian Federation and its adaptability to European and Eurasian integration Project. In: PETROV, Roman; ELSUWEGE, Peter (Eds.). Post-Soviet Constitutions and Challenges of Regional Integration. Adapting to European and Eurasian Integration Projects. Abingdon: Routledge, 2018, p.168-177.

KUDRYASHOVA, Ekaterina. Pravovoe regulirovanie strategicheskogo planirovaniia v sfere gosudarstvennykh finansov. Moscow: Institute zakonodatelstva i sravnitelnogo pravovedeniia, 2019.

MALKSOO, Lauri. Russian Approaches to International law. Oxford: Oxford University Press, 2015.

NEUWIRTH, Rostam J.; SVETLICINII, Alexandr. The BRICS-Lawyers' Guide to BRICS Texts and Materials. Macau: BRICS-Lawyers, 2019.

RICCERI, Marco. A report on the ambassador's conference in Rome following the 10th BRICS summit conference. Kutafin University Law Review. Moscow, vol. 6, n. 1, p. 225-234, apr. 2019.

ROLLAND, Sonia E. The BRICS' Contributions to the Architecture and Norms of International Economic Law Proceedings of the Annual Meeting. American Society of International Law, Massachusetts, v. 107, 2013, p. 164-170.

RYAZANOVA, M. O. Energy cooperation within the BRICS: Significance of the issue. Bulletin of MGIMO, Moscow, v. 39, n. 6, p. 7-11, 2015.

SANDREY, Ron; JANSEN, Hans Grinsted. A fresh look at a Preferential Trade Agreement among the BRICS. Stellenbosch: Tralac, 2013. 
SHASHKOVA, Anna; VERLAINE, Michel; KUDRYASHOVA, Ekaterina, On modifications to the Constitution of the Russian Federation in 2020. Russian Law Journal, Moscow, v. 8, n. 1, p. 60-83, 2020.

SHOKHIN, Sergey; KUDRYASHOVA, Ekaterina. Macroeconomic Coordination in the Eurasian Economic Union: Strategic Aspects. Russian Law Journal. Moscow, v. 7, n. 3, 2019, p. 38-52.

SIMÕES, Fernando Dias. A Dispute Resolution Center for the BRICS? In: NEUWIRTH, Rostam J.; SVETLICINII, Alexandr; HALIS, Denis de Castro (Eds.). The BRICS-Lawyers' Guide to Global Cooperation.Campridge: Cambridge University Press, 2017, p. 270-286.

SMITH, K. South Africa, the BRICS and human rights: In bad company? In: KHADIAGALA, Gilbert M.; PILLAY, Devan; SOUTHALL, Roger (Eds.). New South African Review 5: Beyond Marikana. Johannesburg: University of Witwatersrand Press, 2015.

WORLD ECONOMIC FORUM. BRICS-plus: Alternative globalization in the making? Available at: $\quad<$ https://www.weforum.org/agenda/2018/01/brics-plus-an-alternative-to-globalization-in-the-making/>. Last accessed: 10 apr. 2020.

ZAKHAROVA, Larissa. The interpretive approach to international law: a positivist view. Kutafin University Law Review, Moscow, v. 2, n.1, p. 136-155, may. 2015.

ПРЕЗИДЕНТ РОССИИ. Послание Президента Федеральному Собранию. Moscow. Available at: <http://www.kremlin.ru/events/president/news/62582>. Last accessed: 20 feb. 2020. 